Cell Research (2001); 11(3):217-222

http://www.cell-research.com

\title{
TNF receptor-associated factor-2 binding site is involved in TNFR75- dependent enhancement of TNFR55-induced cell death
}

\author{
LU FANG, JiA FANG, Chang QING CHEN*
}

Shanghai Research Center of Biotechnology, Shanghai Institutes for Biological Sciences the Chinese Academy of Sciences, Shanghai 200233, China

\begin{abstract}
TNF recepter-55 is the main mediator of TNF-induced apoptosis. TNF receptor-75-dependent induction or enhancement of cytotoxicity has been explained by intracellular signaling, "ligand passing” , or induction of endogenous TNF. To study the function of human TNF receptor-75 (hTR75) and the interaction between human TNF receptor-55 (hTR55) and hTR75 in hTNF $\alpha$-induced cytotoxicity, HEp- 2 cells were transfected with bicistronic expression vector of hTR75 and its deletion mutants genes. hTNFa-induced cytotoxicity was determined by crystal violet colorimetric method. The expression of hTR75 and its deletion mutants in HEp-2 cells was demonstrated by RT-PCR and indirect ELISA. We found that the overexpressed hTR75 could significantly increase the susceptibility of HEp-2 cells to hTNFa which especially required TRAF2 binding site. hTR75 could not only mediate partial hTNFa-induced cytotoxicity independently but also fulfill an accessory role in enhancing or synergizing hTR55-mediated cytotoxicity.
\end{abstract}

Key words: $h T N F \alpha, h T N F$ receptors, TRAF2, cytotoxicity, signal transduction.

\section{INTRODUCTION}

Tumor necrosis factor alpha $(\mathrm{TNF} \alpha)$ is a pleiotropic cytokine that is mainly produced by activated macrophages and lymphocytes[1]. TNFa initiates inflammatory, immune regulatory and pathophysiologic responses by binding to two distinct cell surface receptors of TR55 (55 kDa) and TR75 $(75 \mathrm{kD} \alpha)$ [2]. Both receptors belong to TNF receptor superfamily because they share $28 \%$ homology and contain 4 conserved cysteine-rich subdomain in their extracellular regions[3]. It is the unique structural features of receptors that allow them to recognize TNF with specificity. The ligand binding properties of TR55 and TR75 have been extensively studied. In a recent report the rapid kinetics of TR75 association and dissociation have been taken as a basis to postulate a model termed "ligand passing" in which the ligand bound to TR75 may be passed over to TR55 to enhance TR55 signaling[4].

\footnotetext{
* Correspondence to Prof. Chen Chang Qing, Tel: 86-21-64700892, ext 306. Fax: 86-21-64700244. Email: cqchen@srcb.ac.cn Received March-4-20017nbsp; Revised June-13-2000 Accepted July-15-2001
}

The intracellular domains of the two TNF receptors have no sequence homology, suggesting distinct biological function[2]. Deletion mutagenesis of TR55 revealed that a death domain[5], which consists of about 80 amino acids residues located to the C-terminal portion of the protein's intracellular region, is responsible for death induction and $\mathrm{NF}-\kappa \mathrm{B}$ activation. Intracellular region of TR75 does not possess the death domain or any other domains with intrinsic catalytic activity. An adapter protein, TRAF2 (TNFR-associated factor-2), was found to function as the actual signal transducer in TR75-mediated signaling[6]. The results also indicate that a C-terminal region of 78 amino acids within the cytoplasmic domain of hTNFR-75 comprising amino acids 346-423 is required for signal transduction and TRAF2 binding. Hsu $\mathrm{H}$ et al.[7] have shown that interaction of the death domain protein TRADD with TRAF2 is critically involved in TNFR55-dependent activation of NF- $\kappa \mathrm{B}$.

Thus, the ligand-induced interaction between TR55 and TR75 may have important implications 
in TNF signaling. In order to study the function of human TR75 in hTNFa-induced cytotoxicity in HEp2 cells, we investigated the cytotoxic effects of the wild-type hTNF $\alpha$ and its mutants (R32WS86ThTNFa and D143F- hTNF $\alpha$ ) on the HEp-2 cells which had been tranfected by TR75 gene, TR75 $\triangle$ 1 gene (deletion of TRAF2 binding site) or TR75 $\triangle$ 2 gene (deletion of intercellular domain) compared with the HEp-2 cells.

\section{MATERIALS AND METHODS}

\section{Reagents and kits}

Restriction endonucleases, AMV reverse transcriptase, Tag DNA polymerase, dNTP and RNasin were from Roche or Promega; Geneticin (G-418), TRIzol Reagent, Trypsin and Dulbecco' $\mathrm{s}$ modified Eagle medium (DMEM) were from GIBCO BRL; Newborn bovine serum(NCS) was from Hangzhou Sijiqin Biotechnology Company; McAbs to hTR55 or hTR75 were from R and D Systems, UK; HRP-labeled goat anti mouse IgG, cycloheximide (CHX) were from Sigma; Standard MW markers of nucleic acid were from Takara company; Wild-type hTNF $\alpha$ and its mutants (R32WS86T- hTNF $\alpha$ and D143F- hTNF $\alpha$ ) were expressed in E.coli and purified in our lab.

\section{Plasmid and cell line}

pAD-CMV5-hTR75 (containing hTR75 cDNA) were provided by Dr. Kr?nke M; Expression vector TWOIRES was constructed in our lab; human larynx carcinoma-derived cell line, HEp-2 (Aarhus University, Denmark) was cultured in DMEM containing $10 \% \mathrm{NCS}$ at $37^{\circ} \mathrm{C}$ in $95 \%$ air $+5 \% \mathrm{CO}_{2}$.

\section{Recombinant Vectors Constructions, Expression and Identification}

hTR75 $\triangle-1(\triangle 346-439)$ and $h T R 75 \triangle-2(\triangle 276-461)$ coding regions were amplified by PCR using P1and P2, P1 and P3 primers respectively.

P1: 5' -GAATGGATCCACCGGTATGGCGCCCGTCGCCGT-3' P2: 5' -GATCACGCGTCTCGAGTTAGCTCCCGGTGCTGGC-3' P3: 5' -GATCACGCGTCTCGAGTTATTCTCTCTGCAGGCA-3'

The bicistronic expression vector[8] with EMCV IRES, containing hTR75 gene or its mutants (hTR75 $\triangle-1$ and hTR75 $\triangle$-2) and neoR gene, was constructed and introduced into HEp-2 cells by electroporation. Cells $\left(5 \times 10^{6} \mathrm{in} 1.0 \mathrm{ml}\right)$ were transfected with 10 $\mu \mathrm{g}$ of the plasmid $(376 \mathrm{~V}, 1080 \mu \mathrm{F})$. The next day, G418 was added to a final concentration of $800 \mathrm{mg} / \mathrm{ml}$. About two weeks later, individual colonies were picked up and expanded. Expression of hTR75 and its mutants was monitored by RT-PCR. RNA was prepared by TRIzol Reagent from $2 \times 10^{6}$ cells. After reverse transcription reaction, $\mathrm{PCR}$ was carried out with sense primer (CCGCCCAGGTGGCATTTAC) and antisense primer (ATACTCGAGTGCCCCTGGGGCCA) for hTR75; sense primer $\mathrm{P} 1$ and antisense primer $\mathrm{P} 2$ for hTR75 $\triangle-1$; sense primer $\mathrm{P} 1$ and antisense primer P3 for $h \operatorname{Tr} 75 \triangle-2$. The expression of hTR75 also examined by ELISA. Cells $\left(4 \times 10^{4} /\right.$ well $)$ were seeded into 96 well microtiter plates in $100 \mu \mathrm{l}$ of medium and incubated overnight. The cells were then fixed by $0.25 \%$ glutaraldehyde, and expression of hTR75 was detected by McAbs to hTR75 and anti-mouse IgGHRP.

\section{Competitive binding activity of hTNFa with recep- tors [9]}

Wild-type hTNFa was coated in 96-well microtiter plates at 0 . $2 \sim 1 \mu \mathrm{g} /$ well in $100 \mu \mathrm{l}$ carbonate buffer $(\mathrm{pH} 9.6)$ and incubated overnight at $4^{\circ} \mathrm{C}$. After washing and blocking, hTNF $\alpha$ mutein R32W-S86T-hTNF a or D143F-hTNF $\alpha$ were diluted serially in medium containing hsTR55-preS1 or hsTR75-preS1 fusion receptors, and added to the well. After incubation for $1 \sim 2 \mathrm{~h}$ at $37^{\circ} \mathrm{C}$, HRP labeled anti-HBsAg preS1 McAbs were added. TMB was used as substrate, and optic density was measured at $570 \mathrm{~nm}$.

\section{Cytotoxicity assay}

HEp-2, HEp-2-TR75, HEp-2-TR75 $\triangle$-1 and HEp-2-TR75 $\triangle$-2 cells were seeded into 96 -well microtiter plates at $4 \times 10^{4} /$ well in 100 $\mu \mathrm{l}$ medium and allowed to grow for $22 \sim 24 \mathrm{~h}$. Cycloheximide was added to final concentration of $20 \mathrm{mg} / \mathrm{l}$, and wild- type hTNFa or its muteins was added to the wells in serial dilution. The plates were incubated at $37^{\circ} \mathrm{C}$. At $16 \mathrm{~h}$, the viable cells were stained with staining buffer (22.3\% ethanol containing $0.5 \%$ crystal violet, $8 \%$ methanol, $7 \mathrm{~g} / \mathrm{l} \mathrm{NaCl}$ ) for $1 \sim 2 \mathrm{~h}$. The dye was eluted with $33 \%$ citric acid, and absorbance was measured at $595 \mathrm{~nm}$.

\section{RESULTS}

\section{Characterization of recombinant $h T N F \alpha$ muteins}

Structure-function studies of $\mathrm{hTNF} \alpha$ showed that Asp143 is the key residue for binding to hTR55 while Arg32 and Ser86 are to hTR75[17]. In order to understand the accurate cellular responses mediated by hTR55 or hTR75, the hTR75-specific mutant R32W-S86T- hTNF $\alpha$ and the hTR55-specific mutant D143F-hTNF $\alpha$ were expressed in E.coli and purified. Their exclusive specificity for hTR55 or hTR75 was confirmed by the receptor competitive

Tab 1. Competitive binding assays of hTNF $\alpha$ and its mutant to hTR55 and hTR75

\begin{tabular}{lcc}
\hline \multirow{2}{*}{ Mutants } & \multicolumn{2}{c}{$\begin{array}{c}\text { Relative binding ability } \\
\text { (Mutants/wt) \%) }\end{array}$} \\
\cline { 2 - 3 } & hTR55 & hTR75 \\
\hline Wt-hTNF $\alpha$ & 100 & 100 \\
R32W-S86T-hTNF $\alpha$ & 8.9 & $<0.26$ \\
D143F- hTNF $\alpha$ & $<0.098$ & 5.5 \\
\hline
\end{tabular}


binding assay[9] (Tab 1).

\section{Expression of hTR75 in HEp-2 cells}

The expression of hTR75 in HEp-2 cells at transcription and translation levels were analyzed by RTPCR (Fig 1A) and indirect ELISA (Fig 1B), respectively.

Cytotoxicity assay of HEp-2 and HEp-2-TR75 cells

As showed in Fig 2 and Tab 2, for HEp-2 cells, R32W-S86T-hTNF $\alpha$ presented a little lower cytotoxicity compared with wild-type $\mathrm{hTNF} \alpha$, and D143F-hTNF $\alpha$ was not cytotoxic in the presence of cycloheximide. Compared with HEp-2 cells, HEp-2TR75 cells increased their sensitivity to wild-type hTNF $\alpha$ more than $10^{5}$ folds while HEp- 2-TR75 $\triangle$ -
1 (deletion of TRAF2 binding site) and HEp-2-TR75 $\triangle-2$ (deletion of intercellular region) cells increased their sensitivity to wild-type hTNF $\alpha$ about 100 fold. Meanwhile, HEp-2-TR75 cells increased their sensitivity to the hTR75-specific mutant R32W-S86T$\mathrm{hTNF} \alpha$ about 100 folds after being treated $12 \mathrm{~h}$ together with cycloheximide. However, R32W-S86ThTNFa presented the similar cytotoxicity on HEp2-TR75 $\triangle$-1, HEp-2-TR75 $\triangle$-2 and HEp-2 cells. We also found that Wt hTNFa presented similar cytotoxicity on HEp-2-TR75D-1 and HEp-2- TR75 $\triangle$-2 cells, so did its mutant R32W-S86T-hTNF. Furthermore, cytotoxicity by TR55-specific mutant D143F-hTNFa was observed on HEp-2-TR75 cells in high concentration while D143F-hTNF $\alpha$ was not

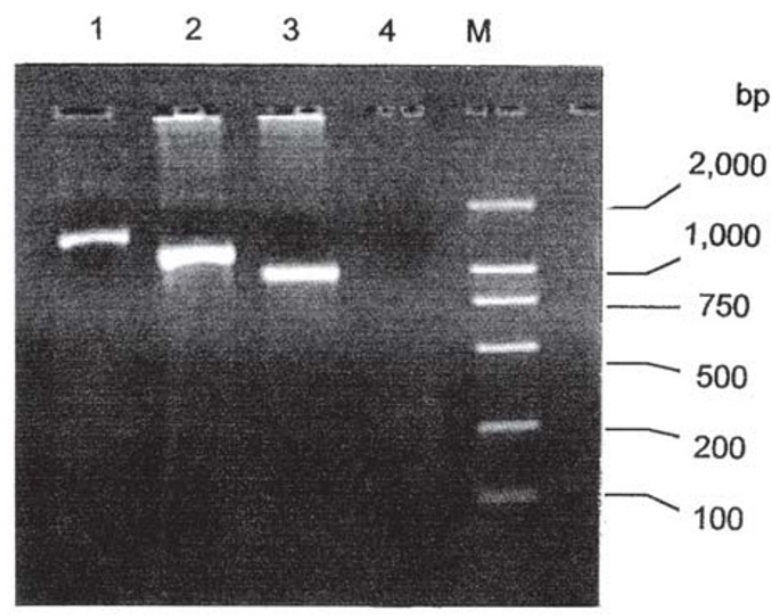

(A)

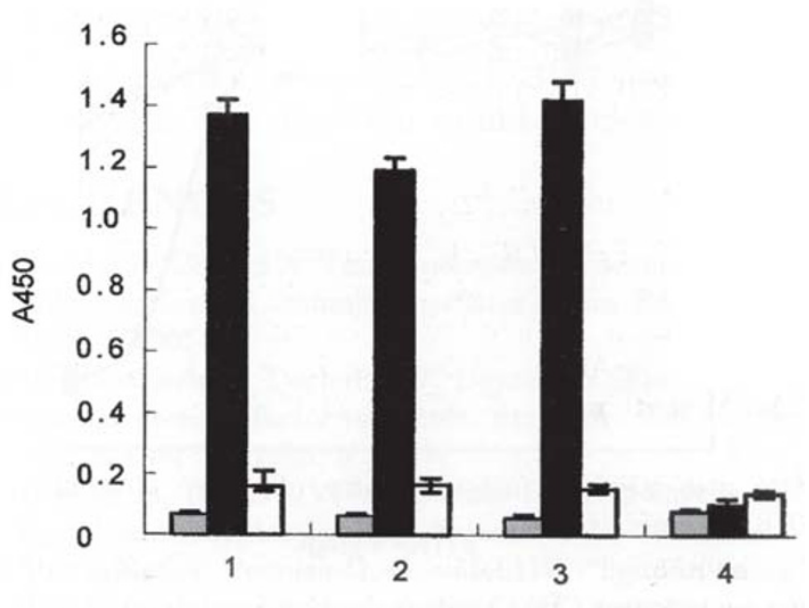

(B)

Fig 1. Identification of HEp-2 cells transfected by hTNFR75 and its mutants (A) RT-PCR analysis; (B) Indirect ELISA 1, HEp-2-TR75 cells; 2, HEp-2-TR75 $\triangle$-1cells; 3, HEp-2-TR75 $\Delta$-2 cells; 4, HEp-2 cells; M, PCR Marker; $\checkmark$, Anti-hTR55; $\square$, Anti-hTR75; $\square$, control.

Tab 2. Cytotoxic activity of hTNFa and its mutants' on HEp-2, HEp-2-TR75, HEp-2-TR75 $\triangle-1$ and HEp-2-TR75 $\Delta-2$ cells

$\operatorname{EC50}(\mathrm{g} / \mathrm{L})$

\begin{tabular}{cccc}
\cline { 2 - 4 } & Wt hTNFa & R32WS86T-hTNFa & D143F-hTNFa \\
\hline HEp-2 & $2.24 \pm 0.139 \times 10^{-6}$ & $1.58 \pm 0.016 \times 10^{-5}$ & $<10^{-2}$ \\
HEp-2-TR75D-1 & $3.1 \pm 0.161 \times 10^{-8}$ & $1.26 \pm 0.117 \times 10^{-5}$ & $<10^{-2}$ \\
HEp-2-TR75D-2 & $4.68 \pm 0.427 \times 10^{-8}$ & $2.0 \pm>0.077 \times 10^{-5}$ & $<10^{-2}$ \\
HEp-2-TR75 & $>10^{-11}$ & $1.0 \times 10^{-7}$ & $3.16 \pm .025 \times 10^{-4}$ \\
\hline
\end{tabular}




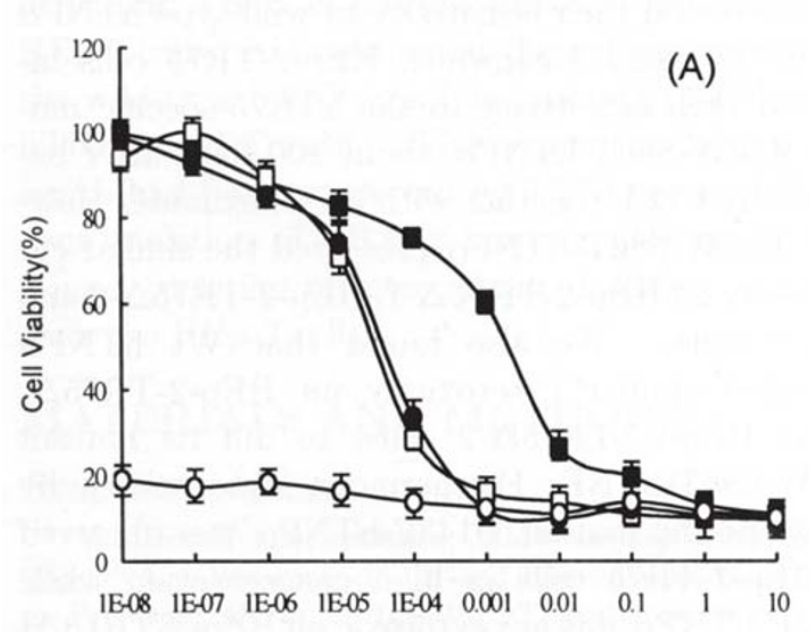

$\rho(\mathrm{TNF}$ a $) / \mathrm{mgL}^{-1}$

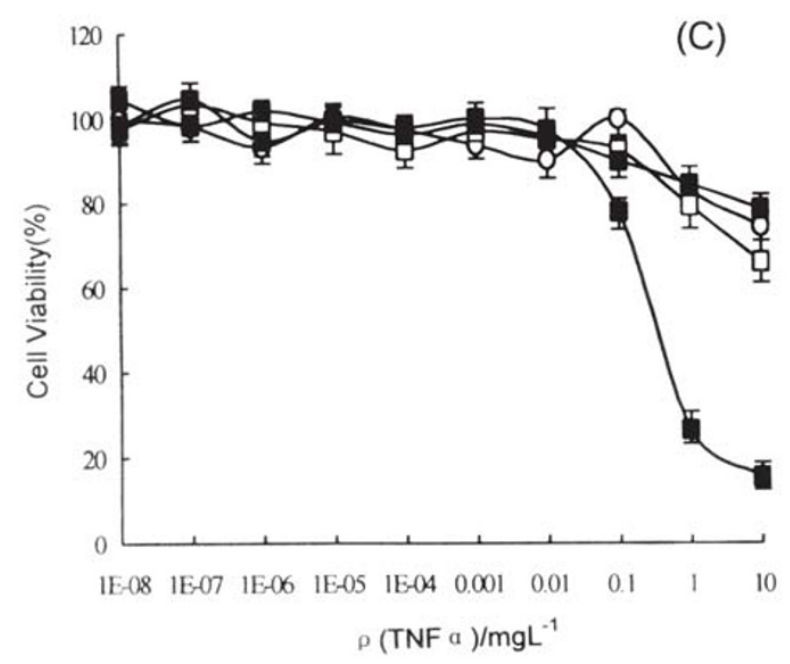

Fig 2. Cytocidal effect of hTNF $\alpha$ on HEp-2 and HEp-2-TR75 cells (12 h) (A) wt-hTNFa (B) hTNF $\alpha$-R32W-S86T (C) hTNF $\alpha$ -

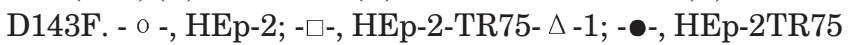
$\Delta-2 ;-$ - - , HEp-2-TR75

cytotoxic on HEp-2-TR75 $\triangle$-1 and HEp-2-TR75 $\triangle$ 2 cells.

\section{DISCUSSION}

Both TNF receptors, TR55 and TR75, are expressed in the majority of cell types and tissues. However, it is established that TR55 is necessary and sufficient for $\mathrm{TNF} \alpha$-induced cellular responses [10] through interacting with several adapter proteins, such as TRADD, FADD, RIP, etc. In contrast, TR75 appears to mediate only a limited

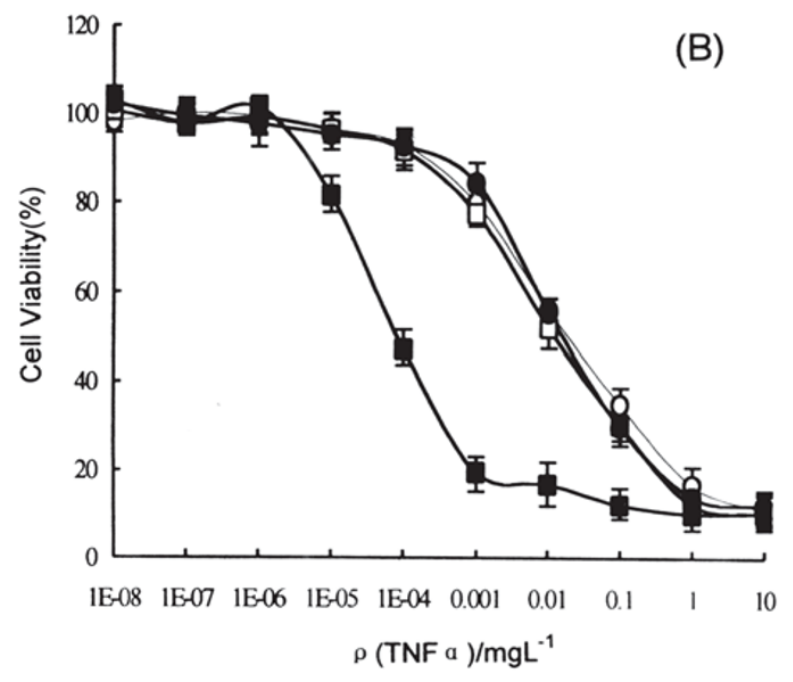

number of cellular responses[11]. Despite the fact that the adapter protein for TR75, TRAF-2 has been identified several years ago, little is known about the accurate mechanism of signal pathways utilized by TR75.

There has been conflicting reports on the involvment of TR75 in TNF-induced cytotoxicity[4]. Tartaglia et al. have shown that TR75 can be involved in the induction of cytotoxicity in a more indirect way by a "ligand passing" effect[4]. Additionally, several independent studies have recently demonstrated that TR75 is capable of signaling apoptosis, especially when it is adequately stimulated by membrane TNF or Agonistic Abs[12-15]. Costimulation of both receptors resulted in additive effects, meaning that probably both receptors initiate this response by use of the same signal transducer. In fact, it has been shown that TRAF2 is necessary for TR75 as well as for TR55-mediated activation of NF- $\kappa \mathrm{B}[7],[16]$.

HEp-2, a human larynx carcinoma-derived cell line, only expresses human TR55 and is susceptible to the cytotoxic action of $\mathrm{hTNF} \alpha$ in the presence of cycloheximide [17]. This made it an ideal model system for studying hTNF $\alpha$ signal pathways. We found that overexpressed hTR75 not only independently mediate cytotoxicity, but also play an accessory role in enhancing or synergizing hTR55-mediated cytotoxicity. However, the cytocidal effect curve of HEp-2-TR75 cells shows that the hTR75-mediated 
cytotoxicity requires high concentrations of both ligand and receptor. It is obviously different from that mediated by hTR55. The exact mechanism of this phenomenon is far from well understood. It is possible that hTR75 clustering after binding to hTNFa is far weaker than hTR55 clustering because the intracellular domain of hTR75 lacks the death domain, which has a strong tendency to self-associate[18]. Furthermore, Grell M[19] recently reported that the affinity of binding to hTNFa and the stability of hTNFa-receptor complex for hTR55 are remarkably higher than those for hTR75 under physiological condition $\left(37^{\circ} \mathrm{C}\right)$. We think the difference on ligand-receptor binding characteristics between hTR55 and hTR75 may also explain the differential behavior of the two receptors.

Our data also show the hTR75-dependent enhancement of hTR55-induced cytotoxicity. In the Fig 2 and Tab 2 showed that TR75 can enhance the hTR55-mediated cytotoxicity intracellular and extracellular. Because compared with HEp-2 cells, HEp-2-TR75 cells increased their susceptibility to wild-type hTNFa more than $10^{5}$ fold whereas HEp2-TR75 $\triangle$-2 (expressing TR75 deletion of intercellular domain) increased their susceptibility about 100 fold. On one hand, the "ligand passing" model could explain why HEp-2-TR75 cells are more susceptible by far to the cytotoxic action of wild-type hTNF $\alpha$ than its muteins. On the other hand, the evidence that hTNFa-induced cytotoxicity to HEp2-TR75 cells was much higher than that to HEp-2TR75 $\triangle-2$ cells (expressing TR75 deletion of intercellular domain) shows that TR75 enhance the TR55- mediated cell death obviously though its intracellular domain. We also found that HEp-2- TR75 cells increased their susceptibility to R32W-S86ThTNFa about 100 folds compared with HEp-2 cells. It is possible that unliganded hTR75 could also synergize hTR55-mediated cytotoxicity through its intracellular domain. Our results also showed that TRAF2 binding site was required by TR75-dependent enhancement of TR55-mediated cytotoxicity for both wild-type hTNF? and its mutant R32W-S86ThTNFa presented similar cytotoxicity on HEp-2TR75 $\triangle-1$ (expressing TR75 deletion of TRAF2 binding site) and HEp-2TR75 $\triangle-2$ cells. It is indicated that the TRAF2 binding site plays important role in the cross talk of TR55 and TR75 intracellular.
It has been shown recently that the network of TNF receptors-induced signal transduction is composed of two main parts, each involving a distinct major protein-binding motif that prompts homophilic protein interaction[20]. One part involves several docking proteins, including FADD, TRADD, RIP, and RAIDD, which bind to each other as well as to TR55 and CD95 through a DD motif found both in the docking proteins and in the receptors. The other part is centered around a group of adapter molecules that share a protein- binging motif called the TRAF domain. The two parts of the network are linked through association of the TRAF domain in the adapter proteins TRAF2 with the regions upstream of the DD in the adapter proteins TRADD and RIP [21], [22]. Hsu H[7] reported that TRADD could also interact with TRAF2 and RIP, and thus stimulates pathways leading to activation of $\mathrm{NF}-\kappa \mathrm{B}$. Therefore, TRAF2 might play a key role in TR55 and TR75 interaction. Now we proved that TRAF2 is also involved in the TR75-dependent enhancement of TR55-mediated cell death. Thus when the above and related questions are further clarified, our knowledge of TNF function would be clearer.

\section{REFERENCES}

[1] Beutler B, Cerami A. Tumor necrosis, cachexia, shock and inflammation: A common mediator. Ann Rev Biochem 1988; 57:505-18.

[2] Vandenabeele P, Declercq W, Beyaert R, Fiers W. Two tumour necrosis factor receptors: Structure and function. Trends Cell Bio 1995; 5:392-9.

[3] Beutler B, Huffel CV. Unraveling function in the TNF ligand and receptor families. Science 1994; 264:667-9.

[4] Tartaglia LA, Pennica D, Goeddel DV. "ligand passing” : The 75-kD tumor necrosis factor (TNF) receptor recruits TNF for signaling by the $55-\mathrm{kDa}$ TNF receptor. J Biol Chem 1993; 268:18542-8.

[5] Tartaglia LA, Ayres TM, Wong GHW, Goeddel DV. A novel domain within the $55 \mathrm{kD}$ TNF receptor signals cell death. Cell 1993 74:845-53.

[6] Rothe M, Wong SC, Henzel WJ, Goeddel DV. A novel family of putative signal transducers associated with the cytoplasmic domain of the $75 \mathrm{kDa}$ tumor necrosis factor receptor. Cell 1994; 78:681-92.

[7] Hsu H, Shu HB, Pan MG, Goeddel DV. TRADD-TRAF2 and TRADD-FADD interactions define two distinct TNF receptor 1 signal transduction pathways. Cell 1996; 84:299308.

[8] Fang J, Zhu B, Wang DB, Chen CQ, Duch MR, Pedersen FS. Overexpressed human TNF Receptor-75 can independently mediate hTNFa-induced cytotoxicity in BHK-21 Cells. Acta Biochimica et Biophysica Sinica 1999; 31(6): 
637-42.

[9] Fang J, Lu F, Chen CQ. Expression and application of hsTR55/Tr75-preS1 fusion receptors. J Cell Mol Immunol, 2001; 17(3):203-9.

[10] Tartaglia LA, Goeddel DV. Two TNF receptors. Immunol Today 1992; 13:151-3.

[11] Baker SJ, Reddy EP. Modulation of life and death by the TNF receptor superfamily. Oncogene 1998; 17:3261-70.

[12] Grell M, P Scheurich, A Meager et al. TR60 and TR80 tumor necrosis factor (TNF)-receptors can indepently mediate cytolysis. Lymphokine Cytokine Res 1993; 12: 143-8. [13] Grell M, Douni E, Wajant H, et al. Related Articles The transmembrane form of tumor necrosis factor is the prime activating ligand of the $80 \mathrm{kDa}$ tumor necrosis factor receptor. Cell 1995; 83:793-802.

[14] Medvedev AE, Sundan A, Espevik T. Related Articles Involvement of the tumor necrosis factor receptor p75 in mediating cytotoxicity and gene regulating activities. Eur J Immunol 1994; 24:2842-9.

[15] Bigda J, Beletsky I, Brakebusch C, Varfolomeev Y, Engelmann H, Bigda J, Holtmann H, Wallach D. Related Articles Dual role of the p75 tumor necrosis factor (TNF) receptor in TNF cytotoxicity. J Exp Med 1994; 180:445-60.

[16] Rothe M, VM Dixit, DV Goeddel. TRAF2-mediated activation of NF-kB by TNF receptor 2 and CD40. Sci- ence 1995; 269:1424-7.

[17] Brockhaus M, Schoenfeld HJ, Schlaeger EJ, Hunziker W, Lesslauer W, Loetscher H. Identification of two types of tumor necrosis factor receptors on human cell lines by monoclonal antibodies. Proc Natl Acad Sci USA 1990; 87: 3127-31.

[18] Haridas V, Darnay BG, Natarajan K, Heller R, Aggarwal BB. Overexpression of the $\mathrm{p} 80 \mathrm{TNF}$ receptor leads to TNF-dependent apoptosis, nuclear factor-kB activation, and c-Jun kinase activation. J Immunol 1998; 160:315262.

[19] Grell M, Wajant H, Zimmermann G, Scheurich P. The type 1 receptor (CD120a) is the high-affinity receptor for soluble tumor necrosis factor. Proc Natl Acad Sci USA 1998; 95:570-5.

[20] D Wallach, EE Varfolomeev, NL Malinin et al. Tumor necrosis factor receptor and Fas signaling mechanism. Annu Rev Immunol 1999; 17:331-67.

[21] Hsu H, Huang J, Shu H-B et al. TNF-dependent recruitment of the protein kinase RIP to the TNF receptor-1 signaling complex. Immunity 1996; 4:387-96.

[22] Takeuchi M, Rothe M, Goeddel DV. Anatomy of TRAF2. Distinct domains for nuclear-kB activation and association with tumor necrosis factor signaling proteins. J Biol Chem 1996; 271:19935-42. 